\title{
MARKETING STRATEGY FOR SOFT BONED MILKFISH MSME PRODUCTS IN SEMARANG CITY DURING THE COVID-19 PANDEMIC
}

\author{
Aldise Kresna Dewi Tutianvia ${ }^{a}$, Agus Suherman ${ }^{b, *}$, Abdul Kohar Mudzakir ${ }^{b}$ \\ aProgram Pascasarjana Manajemen Sumberdaya Perairan, Fakultas Perikanan dan Ilmu Kelautan, \\ Universitas Diponegoro, Semarang, 50275, Indonesia \\ ${ }^{b}$ Departemen Perikanan Tangkap, Fakultas Perikanan dan Ilmu Kelautan, Universitas Diponegoro, \\ Semarang, 50275, Indonesia \\ *Corresponding author: lpgsuherman2@gmail.com
}

\begin{abstract}
Abstrak
Pandemi Covid-19 berdampak signifikan pada berbagai sektor, termasuk Usaha Mikro, Kecil, dan Menengah (UMKM). Salah satu UMKM yang terdampak adalah UMKM bandeng duri lunak. Penelitian ini bertujuan untuk menganalisis dampak pandemi Covid-19 dan menentukan strategi pemasaran produk UMKM bandeng duri lunak di Semarang. Metode yang digunakan dalam penelitian ini adalah metode survey. Data primer diperoleh dari 75 UMKM bandeng duri lunak di Kota Semarang, data sekunder diperoleh dari buku dan jurnal terkait. Analisis data yang digunakan adalah analisis deskriptif dan analisis SWOT. Analisis deskriptif digunakan untuk mengetahui dampak pandemi Covid-19 terhadap pemasaran produk UMKM bandeng duri lunak, analisis SWOT digunakan untuk mengembangkan strategi alternatif UMKM bandeng duri lunak selama masa pandemi COVID-19. Hasil analisis menunjukkan bahwa pandemi Covid-19 berpengaruh terkait penurunan jumlah penjualan produk produksi, jumlah pelanggan dan jumlah permintaan sebesar $>50 \%$. Alternatif strategi pemasaran produk UMKM bandeng lunak di Semarang pada masa pandemi Covid-19 adalah: a) Pencantuman merek (trademark) pada setiap kemasan produk; b) Membuat desain kemasan yang menarik; c) Pendaftaran Izin Usaha, Pengajuan Penerbitan SKP (Surat Keterangan Kelayakan Pengolahan), Pendaftaran SNI dan legalitas; d) Bekerja sama dengan pemasok bahan baku untuk memenuhi permintaan pelanggan; e) Mengubah suasana gerai/toko penjualan dengan menerapkan protokol kesehatan.
\end{abstract}

Kata kunci: Covid-19, Bandeng Duri Lunak, UMKM, Strategi Pemasaran, SWOT

\begin{abstract}
The Covid-19 pandemic has significantly affected various sectors, including Micro, Small, and Medium Enterprises (MSMEs). One of the MSMEs affected is Soft Boned Milkfish, therefore, this study aims to analyze the impact of the Covid-19 pandemic and determine the marketing strategy for Soft Boned Milkfish products in Semarang City. It was conducted using a survey method with primary data obtained from 75 SMEs of Soft Boned Milkfish, as well as secondary data obtained from related books and journals. The data were analyzed descriptively and with SWOT analysis. Descriptive analysis was used to determine the impact of the Covid-19 pandemic on the marketing of the products, while the SWOT was used to develop alternative strategies. The results showed that the Covid-19 pandemic caused a decline in the number of sales, customers, and requests by $>50 \%$. Alternative marketing strategies for Soft Boned Milkfish MSME products during the Covid-19 pandemic include a) Branding with a trademark on each product packaging; b) Creating attractive packaging designs; c) Registration of Business Permit, Submission for Issuance of SKP (Certificate of Eligibility Processing), Registration of SNI and legality; d) Cooperating with raw material suppliers to meet customer demands, and e) Changing the atmosphere of sales outlets/stores by implementing health protocols.
\end{abstract}

Keywords: Covid-19, Marketing Strategy, MSME, Soft Boned Milkfish, SWOT

Article history:

(C2021 at http://jfmr.ub.ac.id

Diterima / Received 15-09-2021

Disetujui / Accepted 26-11-2021

Diterbitkan / Published 22-12-2021 


\section{INTRODUCTION}

The global Covid-19 pandemic has affected various sectors, particularly in the economic sector [15][21][31]. ). Based on the projections of the International Monetary Fund (IMF), the global economy is expected to experience a recession with a growth rate of minus 3\% [16]. In Indonesia, this has a significant impact on tourism, the trade sector, and industry, including Micro, Small, and Medium Enterprises (MSMEs) [14][28]. Based on [30], micro-enterprises are businesses that have a maximum net worth of 50 million rupiahs excluding land and buildings for business premises or have annual maximum sales of 300 million rupiahs. Furthermore, small businesses usually have a net worth of more than 50 million rupiahs up to a maximum of 500 million excluding land and buildings for business premises or annual sales of more than 300 million rupiahs up to a maximum of 2.5 billion. Medium-sized businesses refer to enterprises with a net worth of more than 500 million rupiahs up to a maximum of 10 billion excluding land and buildings for business premises or have annual sales of more than 2.5 billion up to a maximum of 50 billion.

MSMEs play an important role in maintaining the nation's economy [32][41][25][37]. They have proven to absorb a larger workforce with the percentage of employment increasing from $96.99 \%$ to $97.22 \%$ between 2012 - 2017. With the large number of workers absorbed, this sector tends to increase people's income, as well as reduce unemployment and poverty. One of the MSMEs from various types of businesses in Central Java is the fishery sector, specifically Processed Fishery of Soft Boned Milkfish. The Soft Boned Milkfish is a processed fishery product produced with raw fish materials treated by sorting, weeding, washing, soaking, packaging, steaming, cooling, packing, marking, and storage [35][29]. [19] explained that the cooking process for 4 hours with a Pressure Cooker capacity of $50 \mathrm{~kg}$ affected the organoleptic, proximate, and hardness values of Soft Boned Milkfish. Besides, the large numbers of milkfish processors makes the business more competitive. The number of
Milkfish MSMEs assisted by the Cooperatives and SMEs Office of Central Java Province in 2021 was 46, this number is the second-highest compared to other districts/cities in the province.

The Covid-19 pandemic had a huge impact on MSMEs due to supply chain uncertainty, decreased production capacity, factory closures, and travel bans [6][34][36][37]. This was also supported by [20] which stated that the impact felt by business entities related to the pandemic was in the fields of marketing, finance, human resources, operations, as well as the SMEs of Soft Boned Milkfish Based on data from the Semarang City Fisheries Service, the sales of Soft Boned Milkfish as typical food have decreased, indicating a solution is needed. Therefore, this study aims to: i) analyze the impact of the Covid-19 pandemic on the marketing of Soft Boned Milkfish MSME products in Semarang City and; ii) determine the marketing strategy.

\section{RESEARCH METHOD}

This study was conducted from December 2020 to August 2021 using a survey method with primary and secondary data. The primary data were obtained from questionnaires distributed to 75 Soft Boned MIlkfish MSMEs in Semarang City and were analyzed descriptively to determine the impact of the Covid-19 pandemic on the marketing of the products. The analysis process used descriptive statistics to determine the index value of respondents' answers and assess the study instrument. [13] explains that the calculation of the index value is as follows.

Index Value $=((\mathrm{F} 1 \times 1)+(\mathrm{F} 2 \times 2)+(\mathrm{F} 3 \times 3)+$ $(\mathrm{F} 4 \times 4)) / \mathrm{n}$

Note:

Fn $=$ Frequency

$\mathrm{n}=$ Number of samples

Meanwhile, the marketing strategy for soft boned milkfish MSME products is carried out using a SWOT analysis [17][33][44]. Several steps in the preparation of a marketing 
strategy for soft boned milkfish products are carried out in the following stages.

1. Identifying SWOT factors (strengths, weaknesses, opportunities and threats).

2. Conducting relevant internal factors analysis summary (IFAS) and external factors analysis summary (EFAS) analysis.

3. Develop alternative strategies using the SWOT matrix

\section{RESULT AND DISCUSSION}

\section{Overview of Soft Boned Milkfish MSMEs in Semarang City}

Based on the results, among the 75 MSMEs of Soft Boned Milkfish used as the respondents, only 10 were included in the criteria for Small-Scale Enterprises, while the other 65 are Micro-Scale MSMEs. A total of 44 respondents or $58.67 \%$ are graduates of high school/equivalent, while 49 made the production of Soft Durian Milkfish as the main business/income source and 67 have been running the business for more than 3 years.

Furthermore, $85.33 \%$ of the respondents' business locations are accessible to mediumsized vehicles, while product promotion is majorly through brochures, banners, social media, and door to door both before and during the pandemic. The descriptive analysis results are consistent with [35], which reported that among 30 respondents in Bandeng Presto, the age of the business is more than 10 years and the entrepreneurs have a high school education..

MSMEs of Soft Boned Milkfish not only produce the vacuum but have several variants including crispy, grilled, yellow gravy, amplang crackers, otak-otak, scrambled, meatballs, galatin, pepes, and milkfish stew. Efforts to process milkfish into several diversified products enhance survival by storing in containers and packaging. Besides, the packaging is an important indicator of consumer choice starting from the shape, size, and attractiveness [24]. The price range for the milkfish products starts from Rp. 25,000 to > 100,000 . In marketing the products, the majority of SMEs still use conventional media such as brochures, banners, social media, and door to door.

\section{The Impact of the Covid-19 Pandemic on the Marketing of Soft Boned MIlkfish MSME Products}

The Covid-19 pandemic had a major impact on the fisheries economy [5][18]. Fishing practices are changing as new markets and alternative marketing strategies are being developed with improved post-harvest handling, hygiene, and sanitation practices [2][3][23][12]. Table 2 presents the results of the respondents' responses based on the questionnaire distributed. The results show that there are 10 important points in the business activity of Soft Boned Milkfish MSMEs. The index most affected by the Covid-19 pandemic was a decrease in production with an index of 3.52. This means that the business owners only obtain $50 \%$ of production before the Covid-19 pandemic.

Furthermore, the decrease in production indirectly led to a reduction in the product sales due to the number of requests and customer visits to the store which decreased by $50 \%$. A similar impact due to the Covid-19 pandemic was observed including difficulties in raising business capital as well as an increase in raw material prices and low availability $[8][9][10][11]$. This shows that each of the factors that exist is interrelated to product marketing. The existence of the Covid-19 pandemic has indirectly affected the economy, specifically the SMEs of Soft Boned Milkfish. [42] stated that MSMEs are at the forefront of economic shocks caused by the Covid-19 pandemic, while[42] added that more than 50\% of MSMEs indicated that they could go out of business in the next few months.

However, the Covid-19 pandemic does not affect the price of the Soft Boned Milkfish product. The index with the lowest value was promotion with a value of 1.88 indicating that social media/online marketing are not significantly affected by the Covid-19 pandemic. [37][22] revealed that for MSME business activities to survive during the pandemic, digital marketing is needed through 
Facebook, Google, YouTube, and other mobile applications.

\section{Marketing Strategy for Soft Boned MIlkfish
MSME Products in Semarang City during \\ Marketing Strategy for Soft Boned MIlkfish
MSME Products in Semarang City during the Covid-19 Pandemic}

In this study, the Marketing Strategy for Soft Bone Milkfish MSME Products in Semarang City during the Covid-19 Pandemic was compiled based on IFAS and EFAS analysis. In the IFAS and EFAS analysis, the first step is to identify the internal and external factors of soft thorn milkfish in Semarang (Table 2).

Table 1. The Impact of the Covid-19 Pandemic on Marketing of Soft Boned MIlkfish MSME Products

\begin{tabular}{|c|c|c|c|c|c|c|c|c|}
\hline \multirow{2}{*}{ No } & \multirow{2}{*}{ Statement } & \multicolumn{4}{|c|}{ Score } & \multirow{2}{*}{$\begin{array}{c}\text { Number of } \\
\text { Respondents }\end{array}$} & \multirow{2}{*}{ Index } & \multirow{2}{*}{ Information } \\
\hline & & 1 & 2 & 3 & 4 & & & \\
\hline 1 & $\begin{array}{l}\text { The Covid-19 pandemic } \\
\text { causes a decrease in the } \\
\text { production of Soft Durian } \\
\text { Milkfish }\end{array}$ & 0 & 4 & 28 & 43 & 75 & 3.52 & $\begin{array}{l}\text { Total production } \\
\text { decreased }>50 \%\end{array}$ \\
\hline 2 & $\begin{array}{l}\text { The Covid-19 pandemic } \\
\text { causes a decline in annual } \\
\text { sales results }\end{array}$ & 0 & 4 & 30 & 41 & 75 & 3.49 & $\begin{array}{l}\text { Annual sales } \quad \text { yield } \\
\text { decreased } \leq 50 \%\end{array}$ \\
\hline 3 & $\begin{array}{l}\text { The Covid- } 19 \text { pandemic } \\
\text { causes the number of } \\
\text { customers who come to the } \\
\text { store/place of sale to decrease }\end{array}$ & 0 & 5 & 29 & 41 & 75 & 3.48 & $\begin{array}{l}\text { The number of customers } \\
\text { who come to the store } \\
\text { decreased } \leq 50 \%\end{array}$ \\
\hline 4 & $\begin{array}{l}\text { The Covid- } 19 \text { pandemic has } \\
\text { reduced people's buying } \\
\text { interest in Soft Boned } \\
\text { MIlkfish products }\end{array}$ & 0 & 4 & 32 & 39 & 75 & 3.46 & $\begin{array}{l}\text { Number of customer } \\
\text { requests decreased } \leq 50 \%\end{array}$ \\
\hline 5 & $\begin{array}{l}\text { The Covid-19 pandemic } \\
\text { causes the selling price of soft } \\
\text { boned milkfish to drop }\end{array}$ & 16 & 42 & 6 & 11 & 75 & 2.16 & $\begin{array}{l}\text { The selling price of Soft } \\
\text { Durian Milkfish before } \\
\text { the pandemic = during the } \\
\text { pandemic (relatively the } \\
\text { same) }\end{array}$ \\
\hline 6 & $\begin{array}{l}\text { The Covid-19 pandemic has } \\
\text { resulted in MSMEs } \\
\text { promoting Soft Boned } \\
\text { MIlkfish through online } \\
\text { promotional media (WA, } \\
\text { Instagram, Twitter) }\end{array}$ & 11 & 63 & 0 & 1 & 75 & 1.88 & $\begin{array}{l}\text { MSME actors have social } \\
\text { media accounts and have } \\
\text { been doing online } \\
\text { promotions before the } \\
\text { pandemic }\end{array}$ \\
\hline 7 & $\begin{array}{l}\text { The Covid-19 pandemic has } \\
\text { resulted in MSMEs } \\
\text { promoting Soft Durian } \\
\text { Milkfish door to door }\end{array}$ & 18 & 34 & 20 & 3 & 75 & 2.14 & $\begin{array}{l}\text { MSME actors before the } \\
\text { pandemic had promoted } \\
\text { door to door, but during } \\
\text { the pandemic they stopped } \\
\text { promoting door to door }\end{array}$ \\
\hline 8 & $\begin{array}{l}\text { The Covid- } 19 \text { pandemic has } \\
\text { resulted in a lack of capital for } \\
\text { MSMEs }\end{array}$ & 1 & 24 & 42 & 8 & 75 & 2.76 & Lack of capital by $\leq 50 \%$ \\
\hline 9 & $\begin{array}{l}\text { The Covid- } 19 \text { pandemic } \\
\text { causes the supply of raw } \\
\text { materials to decrease }\end{array}$ & 1 & 34 & 35 & 5 & 75 & 2.58 & $\begin{array}{l}\text { Raw material supply } \\
\text { reduced } \leq 50 \%\end{array}$ \\
\hline 10 & $\begin{array}{l}\text { The Covid- } 19 \text { pandemic has } \\
\text { reduced the number of human } \\
\text { resources (labor) }\end{array}$ & 5 & 60 & 7 & 3 & 75 & 2.10 & $\begin{array}{l}\text { Fixed number of } \mathrm{HR} \\
\text { (daily/permanent staff) } \\
\text { (before and during the } \\
\text { pandemic) }\end{array}$ \\
\hline
\end{tabular}


Table 2. Identification of Internal and External Factors

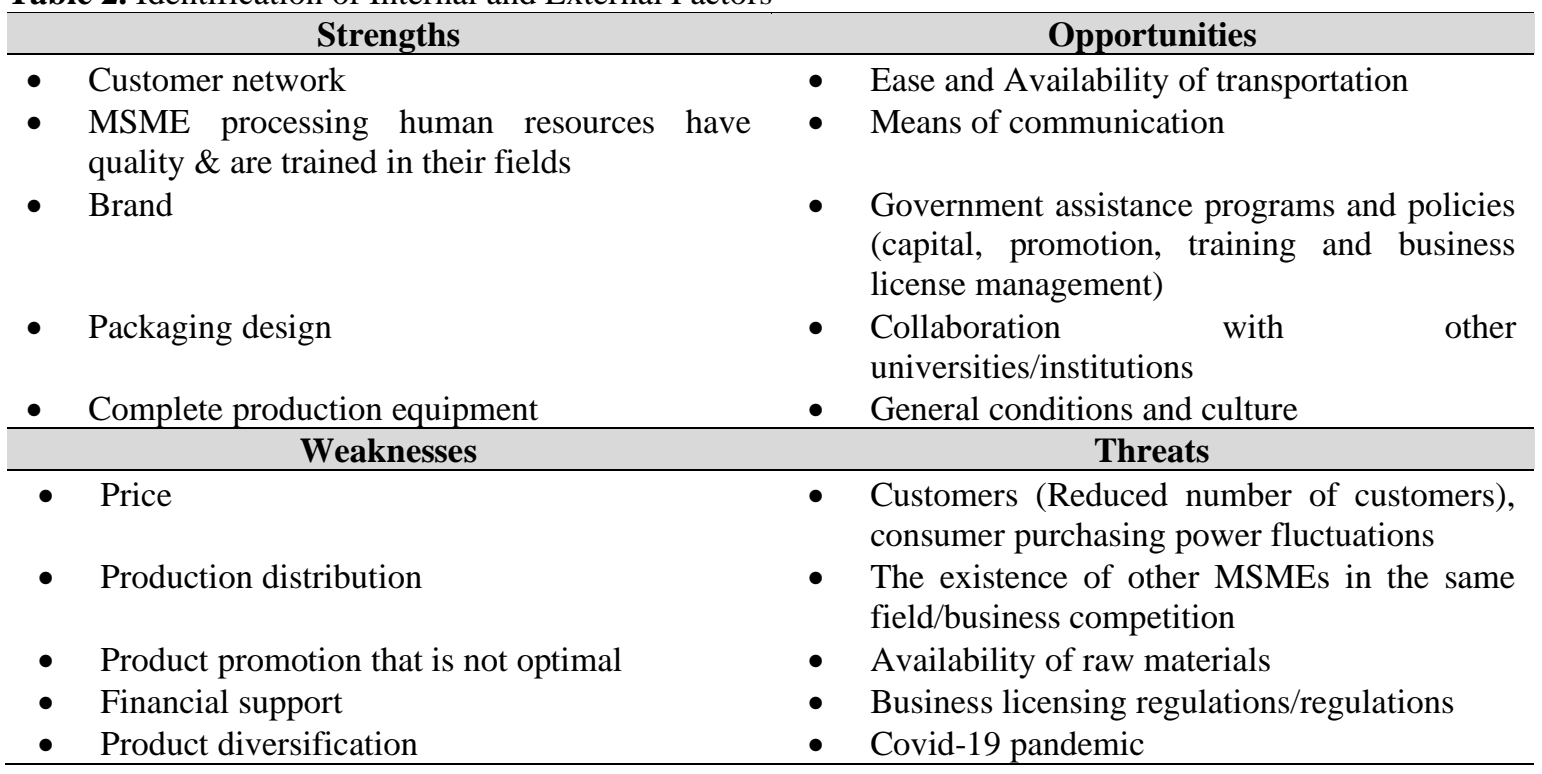

Source: Research Results, 2021

\section{IFAS Strategy}

Based on the data shown in Table 2, IFAS strategy analysis was conducted and the matrix analysis results in Table 3 indicate that the internal factors consist of two components, namely the strengths and weaknesses of 5 attributes. The assessment of the strength and weakness factors obtained a score of 2.54. The customer network from business actors and human resources who have quality and are trained in the respective fields is the biggest strength of the Soft Boned Milkfish MSME in Semarang City with a value of 0.36 , while packaging design is the index with the smallest effect with a value of 0.18 . This shows that in optimizing the marketing of MSME products, there is a need to increase or update the packaging to have a higher aesthetic or selling value [4].

The interview results showed that some MSMEs still use newspapers, plastic, and ordinary paper as product containers, this is one of the inhibiting factors that cause the low selling value of these products. According to [1] MSME actors need to focus on consumer needs by identifying products that are in demand through the marketplace. Unoptimized Prices and product promotions are weaknesses that have the highest influence with a value of 0.3 . This means that the Covid-19 pandemic has caused a change in the public perception towards the selling price of Soft Boned Milkfish and limited access to promotions, thereby indicating the need for a breakthrough, including through social media. Furthermore, production and financial support, as well as product diversification is a weakness that has a low value of 0.18. This is due to the Covid-19 pandemic, which limits access to production, sales and profit maximization as the distribution of products tend to only fulfill demand in the city.

The decline in product demand and sales also causes a decrease in the revenue generated [23][38]. In addition, product diversification is assumed as a weakness because MSME actors have begun to develop various processed products to obtain maximum profit, but from a weakness point of view, the actors are starting to lose focus on the production of soft-dried milkfish (vacuum). 
Table 3. IFAS Analysis

\begin{tabular}{|c|c|c|c|c|}
\hline \multicolumn{5}{|c|}{ Internal factors } \\
\hline No. & Strength & Weight & Rating & Score \\
\hline 1 & Customer network from business actors & 0.12 & 3 & 0.36 \\
\hline 2 & $\begin{array}{l}\text { MSME processing human resources have quality } \& \text { are trained in their } \\
\text { fields }\end{array}$ & 0.12 & 3 & 0.36 \\
\hline 3 & Brand & 0.1 & 2 & 0.2 \\
\hline 4 & Packaging design & 0.09 & 2 & 0.18 \\
\hline 5 & Complete production equipment & 0.1 & 3 & 0.3 \\
\hline \multicolumn{2}{|r|}{ Total Strength Score } & & & 1.40 \\
\hline No. & Weakness & Weight & Rating & Score \\
\hline 1 & Price & 0.1 & 3 & 0.3 \\
\hline 2 & Production distribution & 0.09 & 2 & 0.18 \\
\hline 3 & Product promotion that is not optimal & 0.1 & 3 & 0.3 \\
\hline 4 & Financial support & 0.09 & 2 & 0.18 \\
\hline 5 & Product diversification & 0.09 & 2 & 0.18 \\
\hline \multirow{2}{*}{\multicolumn{2}{|c|}{$\begin{array}{l}\text { Total Weakness Score } \\
\text { Total SW }\end{array}$}} & & & 1.14 \\
\hline & & 1 & & 2.54 \\
\hline
\end{tabular}

Source: Research Results, 2021

\section{EFAS Strategy}

Based on the data shown in Table 1, EFAS strategy analysis was conducted and the matrix analysis results in Table 4 indicate that external factors consist of two components, namely opportunities and threats with 5 attributes. The assessment of opportunity and threat factors scored 2.62, while the highest opportunities factor is the ease and availability of transportation with a value of 0.33 . This is because easier access to facilities and infrastructure such as transportation to reach the Soft Boned Milkfish MSME store increases the number of visiting customers and the profits. In addition, the product is one of the "icon" or typical food of Semarang City.

General conditions and culture are opportunity factors that have the smallest effect of 0.18. Meanwhile, the Covid-19 pandemic has affected all sectors, including tourism, the applicable lockdown and PPKM rules have caused a decrease in product demand due to the limited space for people, local and international tourists, and the economic downturn. The pandemic is the biggest threat faced by Soft Boned Milkfish MSMEs with a value of 0.39 . The emergence of the Covid 19 pandemic outbreak since the end of 2019 has majorly affected life, and the business world is no exception. People's fear of this pandemic requires leads to self-isolation, schools are held at home, and food stalls are limited in operating hours. This is in line with [40][43] which stated that the most obvious impact of the Covid-19 pandemic is the economic and social impact due to restrictions or social distancing and layoffs. It also forces every effort to turn its strategy around, while some even get into a crisis. 
Table 4. EFAS Analysis

\begin{tabular}{|c|c|c|c|c|}
\hline \multicolumn{5}{|c|}{ External Factors } \\
\hline No & Opportunity & Weight & Rating & Score \\
\hline 1 & Ease and availability of transportation & 0.11 & 3 & 0.33 \\
\hline 2 & Means of communication & 0.1 & 2 & 0.2 \\
\hline 3 & $\begin{array}{l}\text { The existence of government assistance programs and policies (capital, } \\
\text { promotion, training and business license management) }\end{array}$ & 0.08 & 3 & 0.24 \\
\hline 4 & Collaboration with other universities/institutions & 0.08 & 3 & 0.24 \\
\hline 5 & General conditions and culture & 0.09 & 2 & 0.18 \\
\hline \multicolumn{2}{|r|}{ Total Opportunity Score } & & & 1.19 \\
\hline No & Threat & Weight & Rating & Score \\
\hline 1 & $\begin{array}{l}\text { Customers (reduced number of customers), fluctuations in consumer } \\
\text { purchasing power }\end{array}$ & 0.11 & 3 & 0.33 \\
\hline 2 & The existence of other MSMEs in the same field / Business Competition & 0.09 & 2 & 0.18 \\
\hline 3 & Availability of raw materials & 0.11 & 3 & 0.33 \\
\hline 4 & Business licensing regulations/regulations & 0.1 & 2 & 0.2 \\
\hline 5 & Covid-19 pandemic & 0.13 & 3 & 0.39 \\
\hline \multicolumn{2}{|r|}{ Total Threat Score } & \multirow{2}{*}{\multicolumn{2}{|c|}{1}} & 1.43 \\
\hline & Total OT & & & 2.62 \\
\hline
\end{tabular}

Source: Research Results, 2021

\section{SWOT Grand Strategy Matrix}

The results of the SWOT analysis obtained a value of $(0.13:-0.12)$ which came from subtraction between the total number of factors $\mathrm{S}$ with $\mathrm{W}(1.40-1.14=0.26)$ and factor $\mathrm{O}$ with $\mathrm{T}(1.19-1.43=-0.24)$, finally $(0.26:-$ $0.24)$ was simplified to $(0.13:-0.12)$, It means the MSME product of Soft Boned Milkfish in
Semarang City is in Quadrant II namely diversification which refers to a strategy that considers strengths and carefully minimize threats that might occur by utilizing existing strengths [33]. This means that the Soft Boned Milkfish MSME is in a stable condition but faces a number of serious challenges which are estimated to continue when it relies only on the previous strategy. A SWOT analysis diagram of the priority marketing strategy during the Covid-19 pandemic is presented in Figure 1.

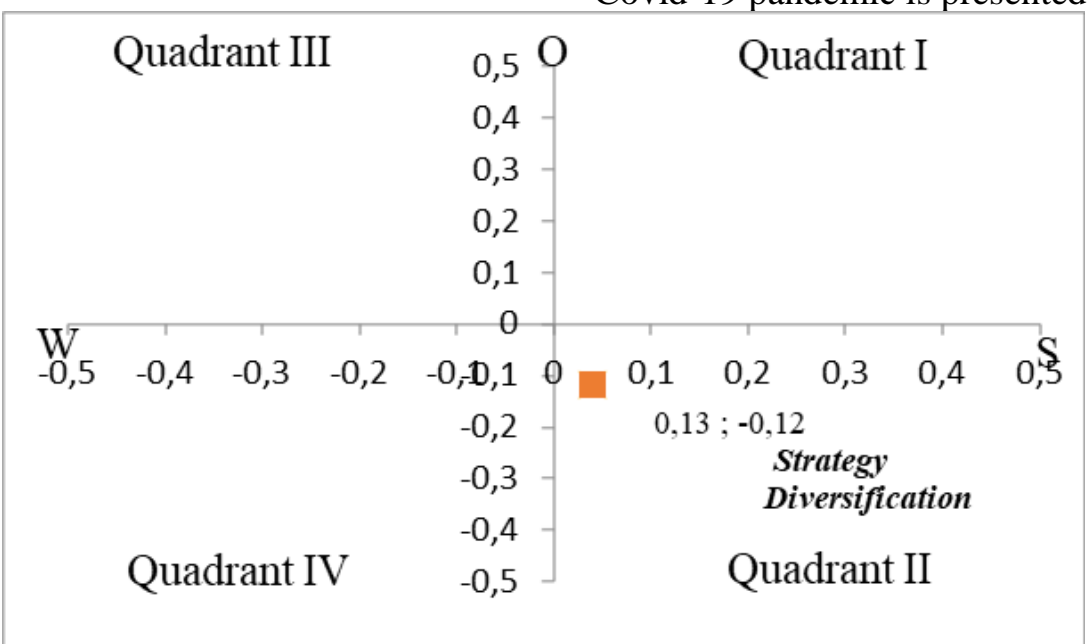

Figure 1. SWOT Matrix Grand Strategy

(Source: Research Results, 2021) 


\section{Alternative Strategy for Soft Boned MIlkfish MSMEs During the Covid-19 Pandemic}

The strength of the Soft Boned Milkfish MSME lies in the customer network of business actors. MSMEs were able to survive during the pandemic by using various network channels to market the products. The customer network in question includes the government organizations such as Semarang City and Central Java Provincial Marine and Fisheries Service, media including newspapers and radio, or from the community. Meanwhile, the weakness of the Soft Boned Milkfish MSME lies in the price and promotion factors. MSMEs are often faced with price volatility of raw materials and supporting factors, specifically during the pandemic when the prices become more expensive. Large-Scale Social Restrictions cause various fish markets to close, fishermen do not go to sea, hence, raw materials are scarce and expensive. This has made some MSME actors increase the price of Soft Boned Milkfish, but the majority still maintain prices for continuous purchasing of products by the consumers. The majority of MSMEs also use social media outlets such as WA, Instagram, and Twitter to promote the products before and after the pandemic [7][39][26][27]. However, the weakness in question is that the level of active promotion through online media is still very low

Opportunities for Soft Boned Milkfish MSMEs lie in the "Ease \& Availability of transportation" factor. The availability of an improved variety of online transportation is now an opportunity for SMEs in marketing products. The seller does not need to personally deliver the product ordered, but through an online application, the goods are delivered directly to the intended address. As for shipping outside the city, various existing expeditions make it easier for SMEs in terms of transportation to deliver the products to consumers. Another threat to Soft Boned Milkfish MSME lies in the Covid-19 Pandemic factor. People's fear of this pandemic leads to self-isolation, while several employees are laid off, thereby reducing people's income and purchasing power. Based on the SWOT analysis, an alternative marketing strategy for the Soft Boned Milkfish MSME product during the Covid-19 pandemic is presented in Table 5 .

According to the SWOT calculation and the grand strategy matrix, the score was $\mathrm{S}<\mathrm{T}$, where the threat is greater than the existing strength, hence, the appropriate recommendation is to diversify the strategy. Although the Soft Boned Milkfish MSME is in a stable condition, it faces a number of severe challenges which are estimated to continue when it only relies on the previous strategy. Based on Table 5, the strength and threat (ST) strategy is the most appropriate alternative to be implemented and is as follows:

a. Include the brand (trademark) on each product packaging

b. Creating eye catching packaging designs to foster consumer mindset towards MSME products

c. Registering Business Permits, Submitting Issuance of SKP (Certificate of Feasibility Processing), Registration of SNI and other legalities to increase product competitiveness and increase customer confidence in product quality

d. Cooperating with raw material providers to meet customer demands

e. Changing the atmosphere of sales outlets/stores by implementing health protocols, namely adding hand washing facilities, thermoguns, and others so that consumers can still buy products comfortably during a pandemic 


\begin{tabular}{|c|c|c|}
\hline$\times$ & $\begin{array}{l}\text { STRENGTH }(\mathrm{S}) \\
\text { - Customer network from business actors } \\
\text { - Quality/skills of human resources for processing Soft Duri Milkfish } \\
\text { - Brand } \\
\text { - Packaging Design } \\
\text { - Complete production equipment }\end{array}$ & $\begin{array}{l}\text { WEAKNESS }(\mathrm{W}) \\
\text { - Price } \\
\text { - Product distribution } \\
\text { - Promotion } \\
\text { - Financial condition support } \\
\text { - Product diversification }\end{array}$ \\
\hline $\begin{array}{l}\text { OPPORTUNITIES }(\mathrm{O}) \\
\text { - Ease and availability of transportation } \\
\text { - Means of communication } \\
\text { - Government Assistance/Policy } \\
\text { (Capital, Promotion, Training, } \\
\text { Business License Management) } \\
\text { - Collaboration with other } \\
\text { universities/institutions } \\
\text { - General conditions and culture }\end{array}$ & $\begin{array}{l}\text { STRATEGY (SO) } \\
\text { - Opening both privately owned outlets and filling Government-owned } \\
\text { outlets (Dekranasda Showroom) } \\
\text { - Participate in training to increase human resources organized by the } \\
\text { Government, Universities or other institutions in terms of processing } \\
\text { Soft Durian Milkfish, good packaging techniques, making packaging } \\
\text { designs, product promotion through information technology and the } \\
\text { use of product tools with renewable technology } \\
\text { - Cooperation with the Government, Universities/other institutions in } \\
\text { the fulfillment of capital, business licenses, registered brands, and } \\
\text { production equipment assistance. } \\
\text { - Cooperation with online transportation services in terms of } \\
\text { marketing, one of which is by providing discounts on shipping costs } \\
\text { to consumers }\end{array}$ & $\begin{array}{l}\text { STRATEGY (WO) } \\
\text { - Cooperation with the Government (relevant agencies) in stabilizing } \\
\text { product prices. } \\
\text { - There is a policy from the Government for the Love to Eat Fish } \\
\text { campaign during a pandemic to increase the body's immunity. } \\
\text { - Cooperation with expedition services to facilitate the distribution of } \\
\text { MSME products outside the city or within the city. } \\
\text { - Cooperation between MSME actors and financial institutions to } \\
\text { increase business capital, by providing soft loans with low interest } \\
\text { rates. } \\
\text { - Cooperation with the Government, Universities/other Institutions to } \\
\text { conduct training to create product diversification with good quality. } \\
\text { - Cultural conditions, namely Soft Boned MIlkfish as typical food of the } \\
\text { city of Semarang can be used / included in promotional words to attract } \\
\text { more consumers from outside the city. }\end{array}$ \\
\hline $\begin{array}{l}\text { THREATS (T) } \\
\text { - Customers (reduced number of } \\
\text { customers) } \\
\text { - The existence of other MSMEs in the } \\
\text { same field/business competition } \\
\text { - Availability of raw materials } \\
\text { - Business } \\
\text { Regulations/Regulations Licensing } \\
\text { - Covid-19 pandemic }\end{array}$ & $\begin{array}{l}\text { STRATEGY (ST) } \\
\text { - Include the brand (trademark) on each product packaging } \\
\text { - Creating eye catching packaging designs to foster consumer mindset } \\
\text { towards MSME products. } \\
\text { - Registering Business Permits, Submitting Issuance of SKP, } \\
\text { Registration of SNI Permits and other legalities to increase product } \\
\text { competitiveness and increase customer confidence in product quality. } \\
\text { - Cooperating with raw material providers to meet customer demands } \\
\text { - Changing the atmosphere of sales outlets/stores by implementing } \\
\text { health protocols, namely adding hand washing facilities, thermoguns, } \\
\text { and others so that consumers can still buy products comfortably } \\
\text { during a pandemic. }\end{array}$ & $\begin{array}{l}\text { STRATEGY (WT) } \\
\text { - Reducing production costs so as to reduce product prices } \\
\text { - MSME actors actively promote on social media so that during the } \\
\text { pandemic, consumers can still buy products online } \\
\text { - Creating other product diversification with good quality to increase } \\
\text { competitiveness }\end{array}$ \\
\hline
\end{tabular}




\section{CONCLUSION}

The existence of the COVID-19 pandemic greatly affected the marketing of Soft Boned Milkfish MSME products in Semarang City by causing a decline in the amount of production and annual sales, as well as the number of customers and requests by $>$ $50 \%$. In addition, the pandemic limits production and distribution to only within the city, increases prices of raw materials, thereby causing the raising of capital by managers to be difficult. The SWOT calculation obtained values ranging from $0.13:-0.12$ which means that the position of Soft Boned Milkfish is in quadrant II. Consequently, the diversification of strategies can be carried out by a) Incorporating the brand (trademark) on each product packaging, b) Creating attractive packaging designs, c) Registering Business Permits, Submitting Issuance of SKP (Certificate of Eligibility Processing), Registration of SNI and legality, d) Cooperating with suppliers of raw materials to meet customer demands, and e) Changing the atmosphere of sales outlets/stores by implementing health protocols.

\section{ACKNOWLEDGEMENT}

The authors would like to thank all parties involved in this research and to the reviewers and editorial team of the Journal of Fisheries and Marine Research published by Faculty of Fisheries and Marine Science, Brawijaya University Malang Indonesia who have reviewed the manuscript of this article.

\section{REFERENCE}

[1] A. Aminy and K. Fithriasari, "Analisis Dampak Covid-19 Bagi UMKM di Jawa Timur," Seminar Nasional Official Statistics 2020: Tantangan dan Peran Official Statistics dalam Masa Pandemi. 1522 hlm. 2020.

[2] N. Ayunda, M.R. Sapota, and A. Pawelec, "The Impact of SmallScale Fisheries Activities Toward Fisheries Sustainability in
Indonesia," Interdisciplinary Approaches for Sustainable Development Goals. Springer Professional. 2018.

[3] N. J. Bennett, E. M. Finkbeiner, N. C. Ban, D. Belhabib, S. D. Jupiter, J. N. Kittinger, S. Mangubhai, J. Scholtens, D. Gill, and P. Christie, "The COVID-19 Pandemic, SmallScale Fisheries and Coastal Fishing Communities."

Coastal Management, vol. 48, hal336-347. 2020.

[4] A. Bosch, E. Gkogka, F. S. Le Guyader, F. Loisy-Hamon, A. Lee, L. van Lieshout, B. Marthi, M. Myrmel, A. Sansom, A. C. Schultz, A. Winkler, S. Zuber, and T. Phister, "Foodborne viruses: Detection, risk assessment, and control options in food processing." International Journal of Food Microbiology, vol 285, hal 110-128. 2018.

[5] I. Chanrachkij, P. Laongmanee, J. Lanmeen, T. Suasi, J. Sornkliang, R. Tiaye, N. Yasook, S. Putsa, S.V. Chumchuen, "Severity of the impacts of COVID-19 pandemic on small-scale fisheries of Thailand: a preliminary assessment." Fish for the People, vol 18, hal 43-47. 2020.

[6] K. F. Davis, S. Downs, J. A. Gephart, "Towards Food Supply Chain Resilience to Environmental Shocks," Nature Food, hal 1-12. 2020.

[7] R. H. Elyarni, "Analisis SWOT Terhadap Strategi Pemasaran Layanan SAP Express pada PT. SAP," Jurnal Metris,vol. 1, no 7, hal 81-88. 2016.

[8] FAO, "The state of world fisheries and aquaculture. Rome", 2020a.

[9] FAO, "Summary of the Impacts of the COVID-19 Pandemic on the Fisheries and Aquaculture Sector: Addendum to the State of World Fisheries and Aquaculture. 2020b. 
[10] FAO, "The impact of COVID-19 on Fisheries and Aquaculture-a Global Assessment from the Perspective of Regional Fishery Bodies." Initial Assessment, No. 1. FAO, Rome. 35 pp. 2020c.

[11] FAO, "How is COVID-19 affecting the fisheries and aquaculture food systems." Rome. 5 pp. 2020c.

[12] A. J. G. Ferrer, R. Pomeroy, M. J. Akester, U. Muawanah, W. Chumchuen, W. C. Lee, P. G. Hai, K. K. Viswanathan, "Covid-19 and Small-Scale Fisheries in Southeast Asia: Impacts and Responses," Asian Fisheries Sciences, vol 34, hal 99113. 2021.

[13] I. Ghozali, "Aplikasi Analisis Multivariate Dengan Program IBM SPSS 23 (Edisi 8)," Semarang : Badan Penerbit Universitas Diponegoro. 2016.

[14] W. L. Hardilawati, "Strategi Bertahan UMKM di Tengah Pandemi C Covid-19," Jurnal Akuntansi Dan Ekonomika, vol 10, no 1, hal 89-98. 2020.

[15] M. L. Holshue, C. DeBolt, S. Lindquist, K. H. Lofy, J. Wiesman, H. Bruce, C. Spitters, K. Ericson, S. Wilkerson, A. Tural, G. Diaz, A. Cohn, L. Fox, A. Patel, S. I. Gerber, L. Kim, S. Tong, X. Lu, S. Lindstrom, and S. K. Pillai, "First Case of 2019 Novel Coronavirus in the United States. New England ," Journal of Medicine, vol 382, no 10, hal 929-936. 2020.

[16] International Monetary Fund. World Economic Outlook Update: June 2020. Washington DC: IMF Publishing. 2020.

[17] S. Ikhsan, dan A. Aid, "Analisis SWOT untuk Merumuskan Strategi Pengembangan Komoditas Karet di Kabupaten Pulang Pisau, Kalimantan Tengah," Jurnal Agribisnis Pedesaan, vol. 1, no. 3,hal. 166-177. 2011.
[18] P. Kaewnuratchadasorn, M. Smithrithee, A. Sato, W. Wanchana, N. Tongdee, V. T. Sulit, "Capturing the Impacts of COVID-19 on the Fisheries Value Chain of Southeast Asia," Fish for the People, vol 18, no 2, hal 2-8. 2020.

[19] R. A. Kurniasih, "Karakteristik Kimia, Fisik dan Sensori Ikan Bandeng Presto dengan Lama Pemasakan yang Berbeda," Prosiding Seminar Nasional Lahan Suboptimal ke-8. 2018.

[20] A. D. Kususmastuti, "Pengaruh Pandemi Covid-19 terhadap Eksistensi Bisnis UMKM dalam Mempertahankan Business Continuity Management (BCM)," Jurnal Administrasi Bisnis, vol. 8, no. 3, hal. 224-232. 2020.

[21] Q. Li, X. Guan, P. Wu, X. Wang, L. Zhou, Y. Tong, R. Ren, K. S. M. Leung, E. H. Y. Lau, J. Y. Wong, X. Xing, N. Xiang, Y. Wu, C. Li, Q. Chen, D. Li, T. Liu, J. Zhao, M. Liu, and Z. Feng, "Early transmission dynamics in Wuhan, China, of novel coronavirus-infected pneumonia," New England Journal of Medicine, vol. 382, no. 13, hal. 1199-1207. 2020.

[22] D. Love, E. Allison, F. Asche, B. Belton, R. Cottrell, H. Froehlich, J. Gephart, C. Hicks, D. Little, E. Nussbaume, P. Pinto da Silv, F. Poulain, A. Rubio, J. Stoll, M. Tlusty, A. Thorne-Lyman, M. Troell, W. Zhang, "Emerging COVID-19 Impacts, Responses, and Lessons for Building Resilience in the Seafood System,". Global Food Security 28:100494. .2020.

[23] D. Mardhia, N. Kautsari, L.I. Syaputra, W. Ramdhani, C. O. Rasiardhi, "Penerapan Protokol Kesehatan dan Dampak Covid-19 Terhadap Harga Komoditas Perikanan dan Aktivitas Penangkapan. Indonesian Journal of 
Applied Science and Technology. vol. 1, hal. 80-87. 2020.

[23] I. L. Mariatun, "Pengaruh Saluran Distribusi, Harga dan Promosi terhadap Volume Penjualan pada Home Industri Tempe Putra KL Kecamatan Socah tahun 2016," Jurnal Ilmu dan Pendidikan Ekonomi-Sosial. vol. 1, no. 1, hal. 31-45. 2017.

[24] A. N. F. Mufreni, "Pengaruh Desain Produk, Bentuk Kemasan dan Bahan Kemasan Terhadap Minat Beli Konsumen (Studi Kasus Teh Hijau Serbuk Tocha)," Jurnal Ekonomi Manajemen, vol. 2, no. 2, hal. 48-54. 2016.

[25] M. Muhyiddin, "Covid-19, New Normal, dan Perencanaan Pembangunan di Indonesia," The Indonesian Journal of Development Planning, vol. 4, no. 2, hal. 240-252. 2020.

[26] R. Muttaqin, "Analisis Disruptive Marketing pada Perusahaan Startup (PT. Gojek Indonesia)," Jurnal Kajian Manajemen Bisnis, vol. 9, no. 2, hal. 101-113. 2020.

[27] B. G. H. M. Narto, "Penguatan Strategi Pemasaran Pudak di Tengah Pandemi Covid-19 Untuk Meningkatkan Keunggulan Bersaing Usaha Mikro Kecil Menengah Kota Gresik," Jurnal INTECH Teknik Industri Unoversitas Serang Raya, vol. 6, no. 1, hal. 48-54. 2020.

[28] S. A. Nulhaqim, H. Wibowo, M. Irfan, A. S. Gutama, "Peningkatan Kapasitas dalam Pemasaran Online Bagi Pelaku Usaha Kecil yang Terdampak Kondisi Pandemi Covid19," Kumawula: Jurnal Pengabdian Kepada Masyarakat, vol. 4, no. 1,: 165-176.

[29] T. Nurhayati, R. H. S. Aji, "Emansipasi Melawan Pandemi Global: Bukti dari Indonesia," 'ADALAH. vol. 4, no. 1, 2020.
[30] Pemerintah Republik Indonesia. Undang-Undang Republik Indonesia Nomor 20 Tahun 2008. Jakarta. 2008

[31] R. Pung, C. J. Chiew, B. E. Young, S. Chin, M. I. C. Chen, H. E. Clapham, A. R. Cook, S. MaurerStroh, M. P. H. S. Toh, C. Poh, M. Low, J. Lum, V. T. J. Koh, T. M. Mak, L. Cui, R. V. T. P. Lin, D. Heng, Y. S. Leo, D. C. Lye, and L. W. Ang, "Investigation of Three Clusters of COVID-19 in Singapore: Implications for Surveillance and Response Measures," The Lancet, vol. 395, no. 10229, hal. 1039-1046. 2020.

[32] A. H. Putra, "Peran UMKM dalam Pembangunan dan Kesejahteraan Masyarakat Kabupaten Blora," Jurnal Analisa Sosiologi, vol. 5, no. 2, hal. 40-52. 2016.

[33] F. Rangkuti, "Analisis SWOT Teknik Membedah Kasus Bisnis". Jakarta: PT. Gramedia. 2016.

[34] T. Reardon, A. Mishra, C. S. Nuthalapati, M. F., Zilberman, D.(2020). Covid- 19's disruption of India's transformed food supply chains. Econ. Polit. Wkly. 55 (18), $18-22$.

[35] C. Retnaningsih, B. R. Berta, R. Okti, "Adaptasi Usaha Mikro, Kecil dan Menengah (UMKM) Bandeng Presto Selama Masa Pandemi Covid19 : Studi Kasus di Kota Semarang." Prosiding Seminar Nasional Lahan Suboptimal ke-8 Tahun 2020. 2020.

[36] M. Rizou, I. M. Galanakis, T. M. Aldawoud, C. M. Galanakis, "Safety of foods, food supply chain and environment within the COVID-19 pandemic." Trends Food Sci. Technol. vol. 102, hal. 293-299. 2020.

[37] R. Rosita, "Pengaruh Pandemi Covid-19 Terhadap UMKM di ndonesia," Jurnal Lentera Bisnis, vol. 9, no. 2, hal. 109-120. 2020. 
[38] N. Sari, E. Achyar, M. Leny, "Pengaruh Distribusi dan Promosi Penjualan terhadap Volume Penjualan." Jurnal Ilmu Manajemen. vol. 3, no. 2, hal. 216- 224. 2020.

[39] E. S. Setiyorini, P. N. Bambang, S. Muhammad, "Strategi Pemasaran Produk Olahan Hasil Perikanan pada UMKM Cindy Group," Manajamen IKM. vol. 13, no. 1, hal. 19-28. 2018.

[40] N. Soetjipto, "Ketahanan UMKM Jawa Timur Melintasi Pandemi Covid-19". K-Media: Yogyakarta. 2020.

[41] S. Sofyan, "Peran UMKM (Usaha Mikro, Kecil, dan Menengah) dalam Perekonomian Indonesia," Jurnal Bilancia, vol. 11, no. 1, hal. 33-64. 2017.

[42] E. Sutrisno, "Strategi Pemulihan Ekonomi Pasca Pandemi Melalui Sektor UMKM dan Pariwista," Jurnal Kajian Lembaga Ketahanan Republik Indonesia. vol. 9, no. 1, hal. 641-660. 2020.

[43] A. F. Thaha, "Dampak COVID-19 Terhadap UMKM di Indonesia." BRAND Jurnal Ilmiah Manajemen Pemasaran, vol. 2, no. 1, hal. 147153. 2020.

[44] Y. Zhang, L. Rysiecki, Y. Gong and Q. Gong, "A SWOT Analysis of the UK EV Battery Supply Chain." Sustainability, vol. 12, no. 3, hal. 1-18. 2020. 